\title{
Literature Review: Elements and Criteria Methodology of Enterprise Architecture for E-Government
}

\author{
Ari Cahaya Puspitaningrum \\ STIE Perbanas \\ Jl. Wonorejo Permai Utara V No.16, Wonorejo, Kec. Rungkut, Surabaya, Indonesia \\ e-mail: ari.cahaya@perbanas.ac.id
}

(received: 24 Agustus 2020, revised: 27 Oktober 2020, accepted: 3 Nopember 2020)

\begin{abstract}
Enterprise Architecture (EA) has become a major requirement for organizations to addresses business, data, infrastructure, and information systems. EA Implementation in the government is considered very important to improve the efficiency of electronic-based services. The documentation process is challenging and is often seen as very time consuming, error-prone, and requires the collection of quality data. To create a successful, it requires to emphasize the aspects of EA development properly to prevent failure of the documentation. So, this study aims to identify the aspects of how to develop EA for e-government. The method of this study was literature review of 30 previous studies that related with the topic. Thus, this study analyzed and synthesized the studies and it can be mapped into 2 categories. The mapping consists of 1) elements and 2) criteria methodology of EA development for e-government. The findings are 23 and 11 criteria methodology of development for e-government. This study also provides some reference for further research and also provides insight into EA development for e-government that will be used by practitioners.
\end{abstract}

Keywords: enterprise architecture, e-Government, e-Government EA, EA methodology

\begin{abstract}
Abstrak
Arsitektur perusahaan telah menjadi kebutuhan utama bagi organisasi untuk mengembangkan bisnis, data, infrastruktur, dan sistem informasi. Penerapan arsitektur perusahaan di pemerintahan dinilai sangat penting untuk meningkatkan efisiensi layanan berbasis elektronik. Proses dokumentasi cukup menantang dan sering kali dianggap sangat memakan waktu, rawan kesalahan, dan memerlukan pengumpulan data yang berkualitas. Untuk menciptakan kesuksesan, perlu adanya penekanan pada aspek pengembangan arsitektur perusahaan dengan baik untuk mencegah kegagalan pendokumentasian. Jadi, penelitian ini bertujuan untuk mengidentifikasi aspek bagaimana mengembangkan arsitektur perusahaan untuk e-government. Metode penelitian ini adalah studi pustaka dari 30 penelitian sebelumnya yang berhubungan dengan topik. Dengan demikian, studi ini menganalisis dan mensintesis studi tersebut dan dapat dipetakan menjadi 2 kategori. Pemetaan terdiri dari 1) elemen dan 2) metodologi kriteria pengembangan arsitektur perusahaan untuk e-government. Temuan tersebut adalah 23 dan 11 kriteria metodologi pengembangan e-government. Studi ini juga memberikan beberapa referensi untuk penelitian selanjutnya dan juga memberikan wawasan tentang pengembangan arsitektur perusahaan untuk e-government yang akan digunakan oleh para praktisi.
\end{abstract}

Kata Kunci: arsitektur perusahaan, arsitektur perusahaan e-Government, e-Government, metodologi arsitektur perusahaan

\section{Introduction}

Enterprise Architecture (EA) was introduced for the first time by John Zachman in 1987. EA has become a major need for organizations to address structure organization, business processes, information flows, information systems and infrastructure [1]. Schekkerman [2], defines EA as an approach to coordinate all the aspects organization that form fundamental holistically. EA is holistic that covers a wide spectrum of information, business, technical and management [3]. Based on the definition of EA, it is concluded that EA implementation is very important for an organization because it provides a solution to make the business process more effective. 
In government sector, EA practices are used in developing e-government which aims to improve the efficiency of electronic-based services. Implementation of EA in government sector could be said grow rapidly. According to Siltanen [4], by 2013, 88\% of government organizations have implemented EA. Then, 2014 most government organizations prioritize the implementation of EA projects, so it can be predicted that the use of EA in various state governments will be increase for the following years.

EA development for e-government is influenced by the documentation process which is a crucial process of EA management and often ends with poor documentation [5] [6]. Documentation process of EA is influenced by the level of organizational complexity. The documentation process is challenging and is often seen as very time consuming, error-prone, and requires the collection of quality data [5]. The failure of the documentation process is influenced by the limited systematic approach to develop EA [6] [7]. EA standards that have been found to used as a reference for developing e-government, have different stages to developing enterprise architecture, but have the same concept, it is the transition from the current architecture (As-Is) to the expected architecture (ToBe) [1]. The selection of EA standards for developing e-government needs to be done properly in order to avoid failure in the documentation process. In addition, this standard could not be directly applied in government organizations, because it does not contain elements that exist in a government.

In previous studies, there was not enough research on the process of developing enterprise architecture documentation for e-government. Several studies conducted by [8] [9] [10] [11] have discussed the developing of a master plan for government, but it is not systematically explained regarding its stages and there is no explanation of the aspects needed in developing an enterprise architecture for e-government.

Based on the problems and previous studies, this study cover 2 aspects discussions of develop EA for e-government, those are: 1) elements EA development for e-government; 2) criteria of EA development for e-government. This study uses literature review method by collecting 30 previous studies related to the development of egovernment EA taken from 5 databases. Next, do the analysis and mapping the subject of each of the studies. This study provides some guidelines for further research related to this topic and also provides knowledge about developing EA for e-government that can be used by practitioners.

\section{Literature Review}

EA is holistic in that it covers a wide spectrum of information, business, technical and management [3]. Based on the understanding of EA, it's concluded that EA is very important for an organization because it can provide a solution to make the business process more effective. Several studies have recommended various enterprise architecture implementation methodologies (e.g. TOGAF, DoDAF, TEAF, FEAF) for use by academics or practitioners in developing EA [1]. The various methodologies of EA implementation have different stages, but they have the same concept, it is the transition from the current architecture (As-Is) to the expected architecture (To-Be) [1]. The EA development stage includes the process of creating, updating, and managing the evolution of all architectural domains in harmony with business strategy [1].

The previous studies conducted by [8] [9] [10] [11] have discussed the developing of a master plan for government, but it is not systematically explained regarding its stages and there is no explanation of the aspects needed in developing an enterprise architecture for e-government. Besides that, the previous literature review studies have not discussed about documentation EA in egovernment, but in general [12] [13] [14].

According to S.Aier [15], the ineffective EA development is due to the complexity of the processes, methods, and strategies used [15]. Thus, it is important for this study to help eliminate these complexities by identifying the elements and methodology criteria for the EA development for e-government. Several previous studies have discussed many of the elements, and methodology criteria but they do not use review literature as a method research of this study. 


\section{Research Method}

The research method in this study is the literature review, which follows Kitchenham and Charters [16] practical guidelines, which consists of three main stages: planning, execution, and result analysis. In this study, researches follows the stages which involves defining the research objectives and the way the review is carried out.

\subsection{Search process}

The literature search process for this study is more oriented towards journal and conference searches than books or reports. This process is the activity of choosing the previous studies and entering the keywords that accordance with the research objectives of this study. Sources selected for the previous study search process are well-known online databases:

- IEEE Xplore

- Science Direct

- Springer Link

- Emerald

- Google Scholar

The keywords used to search studies are keywords that have relevance to this study topic includes : "enterprise architecture", "enterprise architecture for government", "enterprise architecture design", "e-government master plan", "e-government planning", "enterprise architecture framework", "national enterprise architecture", "e-government enterprise architecture" , "government enterprise architecture", "framework for e-government", "government architecture". The search process is done on the title, abstract, and keyword by using predefined keywords.

\subsection{Inclusion and Exclusion Criteria}

At this stage, the researchers determines the inclusion and exclusion criteria that will be used to analyze and eliminate the studies included in the exclusion criteria and to take the study included in the inclusion criteria. Here are the inclusion and exclusion criteria used :

1) Inclusion Criteria:

- English peer-reviewed studies

- Journals and conferences published in 2004-2017

- The studies related to research objectives of this study

- The studies focuses on enterprise architecture development

2) Exclusion Criteria:

- Studies are not English

- Studie has duplication / redundancy

- Not related to research objectives of this study

- Thesis

- Books

\subsection{Studies Selection}

At this stage is the selection stage of previous studies based on the search results in the source used in this study. Selection of studies conducted through 3 process, there are :

1) Studies found: studies that found in the search process based on predetermined keywords

2) Candidate studies: studies that have been selected based on inclusion and exclusion criteria, as well as studies that have titles and abstracts relevant to this study

3) Selected studies: candidates studies are read, analyzed, reviewed from background, analysis of results, discussion, conclusions align with this research objectives. Then, its found the selected studies that will be used in this study 
Table 1. Studies Selection Process

\begin{tabular}{|l|c|c|c|}
\hline \multicolumn{1}{|c|}{ Source } & Found & Candidates & Selected \\
\hline IEEE Xplore & 815 & 35 & 13 \\
\hline $\begin{array}{l}\text { Science Direct }- \\
\text { Elsevier }\end{array}$ & 53 & 6 & 4 \\
\hline Springer Link & 208 & 10 & 3 \\
\hline Emerald & 124 & 20 & 7 \\
\hline Google Scholar & 255 & 31 & 3 \\
\hline Total & 1455 & 102 & 30 \\
\hline
\end{tabular}

Table 1 shown that the studies search was carried out in 5 sources, those are: IEEE Xplore, science direct, springer link, emerald, google scholar. There are 1455 studies that have been found based on predetermined keywords and there are 102 studies that have titles and abstracts that are relevant to this research. In the end, after being reviewed, there were 30 studies that align the objectives of this study. Most selected studies were obtained from IEEE Xplore.

Next, in Table 2 it is shown that the 30 selected studies are journals and conferences. The percentage of conferences is greater than journals, so it can be concluded that this study uses more conferences to be reviewed.

Table 2. Number And Percentage Of Studies

\begin{tabular}{|l|c|c|}
\hline \multicolumn{1}{|c|}{ Studies Type } & Number & $\%$ \\
\hline Journal & 13 & $43,33 \%$ \\
\hline Conference & 17 & $56,67 \%$ \\
\hline
\end{tabular}

\subsection{Identification and Clasification}

In this section, the researchers identifies the theme of the studies that have been selected. The 30 selected studies were given IDs to facilitate the studies mapping in the next section. After identification the studies, researchers found 2 major themes. The 2 themes related to this research objectives. In this section is also shown the description and classification of studies into the 2 major themes.

Table 3. Description and Clasification

\begin{tabular}{|c|c|c|}
\hline Themes & Description & Study ID \\
\hline $\begin{array}{l}\text { Elements in } \\
\text { EA } \\
\text { development } \\
\text { for } \\
\text { e-government }\end{array}$ & $\begin{array}{l}\text { In the context of EA } \\
\text { needs to involve the } \\
\text { elements that must } \\
\text { exist in the EA } \\
\text { development process } \\
\text { for e-government, so } \\
\text { that it could be in } \\
\text { accordance with the } \\
\text { conditions of relevant } \\
\text { government } \\
\text { organizations. }\end{array}$ & $\begin{array}{l}\text { S1;S2;S3;S4;S5;S6;S7; } \\
\text { S8;S9;S10;S11;S12;S13; } \\
\text { S14;S15;S16;S17;S18; } \\
\text { S19;S20;S21;S22;S23;S24. }\end{array}$ \\
\hline $\begin{array}{l}\text { Criteria for } \\
\text { EA } \\
\text { development } \\
\text { methodologies }\end{array}$ & $\begin{array}{l}\text { In an effective EA } \\
\text { development } \\
\text { methodology it is } \\
\text { necessary to have } \\
\text { several criteria. }\end{array}$ & S25;S26;S27;S28;S29;S30 \\
\hline
\end{tabular}

Table 3 shown the mapping results of selected studies that discuss the elements and criteria for 
the EA development methodology. There are 24 studies on the elements used, while there are 6 studies on the criteria for the EA development methodology.

\section{$4 \quad$ Result and Analysis}

Based on the selection of studies that have been done, the researchers then extracted data from 30 selected studies. In this section, researchers describes the findings and discusses the results of review 30 selected studies to meet research objectives that determined in this literature review research.

\subsection{Elements in EA Development for E-Government}

The first objective of this study is related to the process of developing an EA for e-government, which needs to includes the elements that should be within a government organization. It requires to be in accordance with the conditions of organization governments. This section shown the results of extraction and identification of what elements of EA development for e-government that found of each selected studies. Then, calculate what elements are most discussed by the studies, so it's found the key elements of EA development for e-government.

Table 4. Elements EA for E-Gov of The Selected Studies

\begin{tabular}{|l|l|}
\hline Elements & Study ID \\
\hline Vision and mission, objective & $\mathrm{S} 1 ; \mathrm{S} 2 ; \mathrm{S} 4 ; \mathrm{S} 5 ; \mathrm{S} 6 ; \mathrm{S} 7 ; \mathrm{S} 8 ; \mathrm{S} 10 ; \mathrm{S} 11 ;$ \\
strategy, and policy & $\mathrm{S} 12 ; \mathrm{S} 20 ; \mathrm{S} 21 ; \mathrm{S} 22$ \\
\hline $\begin{array}{l}\text { Enterprise } \\
\text { principles }\end{array}$ & $\mathrm{S} 1 ; \mathrm{S} 2 ; \mathrm{S} 4 ; \mathrm{S} 5 ; \mathrm{S} 6 ; \mathrm{S} 7 ; \mathrm{S} 8 ; \mathrm{S} 10 ; \mathrm{S} 11 ;$ \\
\hline Structure organization & $\mathrm{S} 4 ; \mathrm{S} 20 ; \mathrm{S} 21 ; \mathrm{S} 22$ \\
\hline Sponsor / Stakeholder & $\mathrm{S} 5 ; \mathrm{S} 6 ; \mathrm{S} 7 ; \mathrm{S} 10 ; \mathrm{S} 16 ; \mathrm{S} 18 ; \mathrm{S} 20$ \\
\hline Current conditions & $\mathrm{S} 1 ; \mathrm{S} 2 ; \mathrm{S} 3 ; \mathrm{S} 4 ; \mathrm{S} 5 ; \mathrm{S} 7 ; \mathrm{S} 8 ; \mathrm{S} 11 ; \mathrm{S} 12 ; \mathrm{S} 13$ \\
\hline SWOT & $\mathrm{S} 10 ; \mathrm{S} 12$ \\
\hline Critical Success Factor & $\mathrm{S} 10 ; \mathrm{S} 12$ \\
\hline Target analysis & $\mathrm{S} 1 ; \mathrm{S} 4 ; \mathrm{S} 5 ; \mathrm{S} 7 ; \mathrm{S} 8 ; \mathrm{S} 13$ \\
\hline Gap analysis & $\mathrm{S} 1 ; \mathrm{S} 5 ; \mathrm{S} 6 ; \mathrm{S} 7 ; \mathrm{S} 8 ; \mathrm{S} 13$ \\
\hline Government Regulations & $\mathrm{S} 4 ; \mathrm{S} 5 ; \mathrm{S} 6 ; \mathrm{S} 18$ \\
\hline Business Process & $\mathrm{S} 1 ; \mathrm{S} 2 ; \mathrm{S} 3 ; \mathrm{S} 5 ; \mathrm{S} 6 ; \mathrm{S} 7 ; \mathrm{S} 8 ; \mathrm{S} 10 ; \mathrm{S} 12 ;$ \\
& $\mathrm{S} 15 ; \mathrm{S} 18 ; \mathrm{S} 19 ; \mathrm{S} 20 ; \mathrm{S} 21 ; \mathrm{S} 22 ; \mathrm{S} 23 ; \mathrm{S} 24$ \\
\hline Data Integration & $\mathrm{S} 1 ; \mathrm{S} 2 ; \mathrm{S} 4 ; \mathrm{S} 5 ; \mathrm{S} 7 ; \mathrm{S} 8 ; \mathrm{S} 12 ; \mathrm{S} 18 ; \mathrm{S} 22 ; \mathrm{S} 23$ \\
\hline Information / knowledge & $\mathrm{S} 5 ; \mathrm{S} 9 ; \mathrm{S} 12 ; \mathrm{S} 15 ; \mathrm{S} 19 ; \mathrm{S} 21 ;$ \\
& $\mathrm{S} 20$ \\
\hline Application & $\mathrm{S} 1 ; \mathrm{S} 2 ; \mathrm{S} 3 ; \mathrm{S} 4 ; \mathrm{S} 5 ; \mathrm{S} 6 ; \mathrm{S} 7 ; \mathrm{S} 8 ; \mathrm{S} 9 ; \mathrm{S} 10 ; \mathrm{S} 12 ;$ \\
& $\mathrm{S} 18 ; \mathrm{S} 20 ; \mathrm{S} 21 ; \mathrm{S} 22 ; \mathrm{S} 23 ; \mathrm{S} 24$ \\
\hline Application Priotization & $\mathrm{S} 1 ; \mathrm{S} 6 ; \mathrm{S} 12 ; \mathrm{S} 23$ \\
\hline Network Infrastructure & $\mathrm{S} 1 ; \mathrm{S} 2 ; \mathrm{S} 3 ; \mathrm{S} 4 ; \mathrm{S} 5 ; \mathrm{S} 6 ; \mathrm{S} 7 ; \mathrm{S} 8 ; \mathrm{S} 9 ; \mathrm{S} 10 ; \mathrm{S} 12 ;$ \\
& $\mathrm{S} 15 ; \mathrm{S} 17 ; \mathrm{S} 18 ; \mathrm{S} 19 ; \mathrm{S} 20 ; \mathrm{S} 21 ; \mathrm{S} 22 ; \mathrm{S} 23$ \\
\hline Security & $\mathrm{S} 3 ; \mathrm{S} 5 ; \mathrm{S} 12 ; \mathrm{S} 14 ; \mathrm{S} 15 ; \mathrm{S} 18 ;$ \\
& $\mathrm{S} 21 ; \mathrm{S} 22$ \\
\hline Authorization of access rights & $\mathrm{S} 3 ; \mathrm{S} 5 ; \mathrm{S} 6 ; \mathrm{S} 12 ; \mathrm{S} 17 ; \mathrm{S} 18 ; \mathrm{S} 21$ \\
\hline Services & $\mathrm{S} 3 ; \mathrm{S} 15 ; \mathrm{S} 19$ \\
\hline Aeview by stakeholder & $\mathrm{S} 4 ; \mathrm{S} 1 ; \mathrm{S} 19 ; \mathrm{S} 22$ \\
\hline Roadmap package work & $\mathrm{S} 1 ; \mathrm{S} 5 ; \mathrm{S} 12 ; \mathrm{S} 16$ \\
\hline & $\mathrm{S} 1 ; \mathrm{S} 5 ; \mathrm{S} 7 ; \mathrm{S} 8 ; \mathrm{S} 9 ; \mathrm{S} 10 ; \mathrm{S} 12$ \\
\hline
\end{tabular}


Table 4 shown that there are 23 elements of EA development for e-government that have been discussed in the 24 previous studies. In Table 4 also shown that not all studies input the same elements in developing EAs for e-government. It may caused by limitations of their research.

The most common elements found in previous research is vision, mission, strategy, policy, enterprise architecture principles, business process, data integration, network infrastructure, application, security, current conditions, which indicate that they are the main elements. Where these elements are the principles of architecture and core elements in enterprise architecture.

In the previous study, it was explained that the architecture of vision in the development of EA is able to drive the achievement of targets from architecture that integrate networks, services, applications and organizational needs [17]. In other studies, also stated that in developing EA for egovernment there is a vision architecture design phase, which includes an analysis of vision, mission, goals, and strategies [8] [9] [10] [11] [18] [19] [20] [21] [22].

Related to the principles of architecture, Firmansyah, et al [9] stated that the principle of architecture consists of 4 types, namely business principles, data principles, and application principles [17]. These principles describe what things the organization needs or wants to achieve regarding business, data, applications and technology. Identification and determination of architectural principles is carried out at the design stage of the vision [18].

Analysis of the current conditions of government organizations is needed to find out the problems that are being faced and the conditions of business, data, applications, technologies that exist in the current government organization [19] [23].

Business design in EA development consists of main business activities and business support activities. In addition, there is also a need to align business processes with existing IT within government organizations [24]. Business design results will be input for data design. The existing data needs to be analyzed so that it can understand the flow of data and data integration in government organizations [23][25]. Meanwhile, for the application design consists of the user interface, application services, and data entered in the application.

For network infrastructure design, it is necessary to analyze the needs of network elements, the type of connection needed (internet / intranet), the number of applications built, network access speed, network traffic [23]. Firmansyah, et al also stated that there is a need for service network integration, which includes service privacy, such as firewalls, network monitoring [17]. Security is an important thing in a government. Security is a requirement that can guarantee confidentiality, integrity, and authenticity of users [23]. In the development of e-government also need to build security data and information, access data and information, transparent [17]. security and full access rights considerations [20] [26] [27].

Infrastructure security is one of the most important and least understood problems. In the implementation of e-government, the level of risk is increasing because the use of public networks increases together with a database that stores citizen profiles and government information. Therefore, it is necessary to develop sophisticated security technologies such as firewalls, encryption techniques, and systems that can ensure protection against fraud and other vulnerabilities at all levels of government information infrastructure [25]. In EA, security management is needed [28].

Meanwhile, for elements whose elements are not discussed at the studies, these are: structure organization, sponsor / stakeholder, SWOT, CSF, target analysis, gap analysis, government regulations, information / knowledge, authorization of access rights, review by stakeholders , organization readiness, services, application prioritization, roadmap package. All elements found can be used by academics and practitioners.

\subsection{Criteria for EA Development Methodologies}

For this research objective of this study relates to the criteria of an EA development methodology. Several of EA standards or methodologies have been found and they have different criteria values. In the selected studies, there are 6 studies which evaluating or assessing the EA development methodology. In these studies conducted an assessment based on predetermined criteria. In this study, researchers collected the criteria found in the selected studies and then identified which 
methodologies were most discussed or used in terms of assessment or evaluation of the EA development methodology.

Table 5. Criteria for EA Development Methodologies

\begin{tabular}{|l|l|}
\hline Criteria Methodology & Study ID \\
\hline Ease of use & S26;S27 \\
\hline Ease to learn & S26;S27 \\
\hline Consistent & S26 \\
\hline Practical / no complex & S25; S26; S28; S30 \\
\hline Dynamic / flexible & S25; S26;27 \\
\hline Step by step & $\mathrm{S} 26 ;$ S27;S30 \\
\hline $\begin{array}{l}\text { Includes As-IS and To-be } \\
\text { conditions }\end{array}$ & $\mathrm{S} 27 ; \mathrm{S} 30$ \\
\hline Detailed Design of the & $\mathrm{S} 26 ; \mathrm{S} 28 ; \mathrm{S} 29$ \\
\hline $\begin{array}{l}\text { Completeness } \\
\text { domain }\end{array}$ & $\mathrm{S} 27$ S29;S30 \\
\hline Documentation & $\mathrm{S} 28 ; \mathrm{S} 29$ \\
\hline Structured & $\mathrm{S} 29 ; \mathrm{S} 30$ \\
\hline
\end{tabular}

In Table 5, it is shown that there are 11 criteria for assessment an EA methodology that have been found in 6 studies. The criteria most discussed by the researchers is the "practical / no complex" and "step by step" criteria. This indicates that both criteria are very important in an EA development methodology and it can be used as a reference for researchers who will develop methodology of EA development for e-government to emphasize practicality and create a step-by-step methodology.

The EA development methodology must reduce complexity for the current architecture and desired architecture, and create effective transition plans [29]. The EA methodology needs to have practical guidance properties. Complexity is inherent in all enterprise systems such as e-government so complexity management is very important to facilitate the development of enterprise architecture. However, so far there is no EA development methodology that is effective in terms of complexity when implemented [25].

Then, the step by step criteria on the methodology include detailed design, requirements, maintenance, and continual need to consider more due to lack of consideration in most EAIMs [29]. How complete the methodology guides you through a step-by-step process to create a corporate architecture. In addition, in terms of EA development refers to the availability of step-by-step guidance for a better understanding of the practice / process of implementation [30].

\subsection{Discussion}

This section describes discussions on this literature review study. The first discusses about the overall findings of selected studies reviews. Then, discusses deeply about the findings that align with 2 research objectives in this study. Finally the direction for future work and limitations of this literature review study are represented.

EA practices are used in developing e-government is grow rapidly. In this study, researchers analyze studied that published in 2004 - 2017. Based on a review of 30 selected studies with EA development area, it is found 2 discussion themes that consists of 24 studies were focuses on elements that should be in EA development for e-government, and 6 studies on development methodology criteria.

Next, discuss the findings for each research objectives in this study. The first objective is to find out what elements need to be incorporated into the EA development process for e-government. According to Iyer [17], elements of EA are essential for interact to provide the overall functionality of the system [31]. The findings suggest that there are 23 elements of EA development for egovernment that have been discussed or used by researchers to developing EA.

Elements that are widely used are strategy, vision, mission, business processes, data, technology, applications, and security. But, it does not mean that other elements are not important and not 
incorporated into EA development for e-government. The other elements, such as regulation, information, integration, access, communication, organization readiness, services, commitment / stakeholder support, and application prioritization also needed to be considered to get detailed and precise EA design results. So, this study proposes to use all of 23 elements that have been found.

This study makes it easy for academics and practitioners to develop EA for e-government, it can help reduce development time and reduce failures in the process of enterprise architecture egovernment documentation.

The limitations of this study are in 2004-2017 and only use 5 online databases as a search source. It might be possible that there are missed some studies (journals or conferences) that relevant to the topic of this study which indexed in other databases with published before 2004.

There are several recommendations for further work. Firstly, the identified elements and the methodology of EA development for e-government need to be evaluated by practitioners who are experienced in developing EA or by experts judments. Secondly, explores studies deeply that related to the EA development methodology criteria. Thirdly, it would be very interesting to develop a new methodology of EA development for e-government with a structured and easy-to-implement methodology.

\section{Conclusion}

This study aims to conduct the literature review on how to develop EA for egovernment. The researchers identifies and analyzes what elements need to be incorporated into the EA development for e-government and the criteria of the EA methodology to be easy to implement. To find these, the researchers used suitable studies and analyzed the content of the studies then mapped into 2 categories, those are elements and criteria methodology of developing enterprise architecture e-government. There are 26 elements and 2 criteria that should be prioritized in methodology, so it can be easy to implement the EA development methodology for e-government. This study explores requirements to be known and considered in developing EA for e-government, so it provides knowledge and make it easy for academics and practitioners to develop EA for e-government. EA implementation leads many challenges arise in EA development and in the study allows to address these emerging challenges by providing an overview of the elements and criteria methodology for developing EA e- government.

\section{References}

[1] D. Rouhani, M. N. Mahrin, R. B. Ahmad, and P. Nikfard, "A systematic literature review on Enterprise Architecture Implementation Methodologies.," Information and Software Technology., 2015, doi: https://doi.org/10.1016/j.infsof.2015.01.012.

[2] J. Shekkerman, "Trends in Enterprise Architecture," 2004. http://www.enterprisearchitecture.info/Images/EA\%20Survey/EA\%20Survey\%20 2004\%20IFEAD.PDF.

[3] T. Iyamu, "Implementation Of The Enterprise Architecture Through The Zachman Framework," Journal of Systems and Information Technology, 2013.

[4] J. Siltanen, "Enterprise Architecture in the Finnish public sector - It's the law.," 2015.

[5] M. Hauder, F. Matthes, and S. Roth, "Challenges for automated Enterprise Architecture Documentation," Springer, pp. 21-39, 2012.

[6] Roth, S., Hauder, M., "Enterprise Architecture Documentation: Current Practices and Future Directions," 2013.

[7] M. Farwick, C. M. Schweda, R. Breu, and I. Hanschke, "A situational method for semiautomated Enterprise Architecture Documentation," Springer-Verl Berl Heidelb, 2014, doi: //doi.org/DOI 10.1007/s10270-014-0407-3. 
[8] E. Rasdiana and Y. Bandung, "A Centralized Design of Information Network Architecture for Local Government : Case Study of Hulu Sungai Selatan Regency,” IEEE, 2016.

[9] C. M. Firmansyah and Yoanes, "Designing an Enterprise Architecture Government Organization Based on TOGAF ADM and SONA," IEEE Conf., 2016, doi: 10.1109/ICITSI.2016.7858191.

[10] W. D. Sunindyo, S. Akbar, and Mohammad Iqbal, "Towards a Smart World Class City: Case: Building Bandung ICT Master Plan,” IEEE, 2013, doi: 10.1109/ICTSS.2013.6588102.

[11] I. Y. M. Edward, W. Shalannanda, and Susmini Indriani Lestariningati, "E-Government Master Plan Design with TOGAF Framework : Case Study: Payakumbuh City Government, Indonesia," IEEE Conf., 2014, doi: 10.1109/TSSA.2014.7065957.

[12] E. Putro, A. N. Hidayanto, Meyliana, and Harjanto Prabowo, "The Alignment Factors of Business-IT on Enterprise Architecture : a Systematic Literature Review," IEEE, 2017.

[13] A. E. J. E. Egeten, H. Prabowo, Meyliana, M. Hapsara, and Raymond Kosala, "The General Components of Enterprise Architecture Framework in e-Commerce: A Systematic Literature Review," IEEE Conf., 2017.

[14] D. D. Dang and S. Pekkola, "Systematic Literature Review on Enterprise Architecture in the Public Sector," 2016.

[15] J. S. Aier, "Understanding processes for model-based enterprise transformation planning," Int. J. Internet Enterprise Manage., vol. 7, no. 1, pp. 84-103, 2011.

[16] B. A. Kitchenham and S. Charters, Guidelines for performing systematic literature reviews in software engineering, 10th ed. 2007.

[17] B. Iyer and R. Gottlieb, "The Four-Domain Architecture: An approach to support enterprise architecture design," IBM SYSTEMS JOURNAL, vol. 43, no. 3, Art. no. 3, 2004.

[18] C. Batini, G. Viscusi, and D. Cherubini, "GovQual: A quality driven methodology for EGovernment project planning," Government Information Quarterly, 2009.

[19] S. Buckl, F. Matthes, S. Roth, Christopher Schulz, and Christian M. Schweda, "A Conceptual Framework for Enterprise Architecture Design," Springer Berl. Heidelb., doi: https://doi.org/10.1007/978-3-642-16819-2_4.

[20] X. Wang, Xiongwei Zhou, and Longbin Jiang, "A Method of Business and IT Alignment Based on Enterprise Architecture,” IEEE, 2008, doi: 10.1109/SOLI.2008.4686496.

[21] N. B. Kurniawan and Suhardi, "Enterprise Architecture Design for Ensuring Strategic Business IT Alignment (Integrating SAMM with TOGAF 9.1)," IEEE Conf., 2013, doi: 10.1109/rICTICeVT.2013.6741505.

[22] R. Delima, H. B. Santoso, and J. Purwadi, "Architecture Vision for Indonesian Integrated Agriculture Information Systems Using TOGAF Framework.," IEEE, 2016, doi: 10.1109/IAC.2016.7905691.

[23] F. Belanger and J. S. Hiller, "A framework for e-government: privacy implications," Bus. Process Manag. J., 2006, doi: https://doi.org/10.1108/14637150610643751.

[24] N. D. Mamaghani, F. M. Madani, and Ali Sharifi, "Customer oriented enterprise IT architecture framework," Elsevier, 2011, doi: https://doi.org/10.1016/j.tele.2011.07.001.

[25] R. Winter and R. Fischer, "Essential Layers, Artifacts, and Dependencies of Enterprise Architecture," IEEE, 2006.

[26] Z. Ebrahim and Z. Irani, "E-government adoption: architecture and barriers," Business Process Management Journal, vol. 11, no. 15, Art. no. 15, 2005, doi: http://dx.doi.org/10.1108/14637150510619902.

[27] M. Dadashzadeh, "A New Methodology For Developing The MIS Master Plan," 10.19030/rbis.v13i1.4333, vol. 13, 2009, doi: 10.19030/rbis.v13i1.4333. 
[28] B. Fritscher and Y. Pigneur, "Business IT Alignment from Business Model to Enterprise Architecture," Springer Berl. Heidelb., vol. 83, 2011, doi: https://doi.org/10.1007/978-3-64222056-2_2.

[29] S. Gregor, D. Hart, and N. Martin, "Enterprise architectures: enablers of business strategy and IS/IT alignment in government," Information Technology \& People, 2007, doi: http://dx.doi.org/10.1108/09593840710758031.

[30] F. Nikpay, R. B. Ahmad, B. D. Rouhani, Mohd Naz'ri Mahrin, and Shahaboddin Shamshirband, "An effective Enterprise Architecture Implementation Methodology," Springer-Verl. Berl. Heidelb., 2017, doi: DOI 10.1007/s10257-016-0336-5.

[31] B. Iyer and R. Gottlieb, "The Four-Domain Architecture: An approach to support enterprise architecture design," IBM SYSTEMS JOURNAL, vol. 43, no. 3, 2004.

[32] A. Wegmann, I. Rychkova, G. Regev, and L.-S. Lê, "Business and IT Alignment with SEAM for Enterprise Architecture,” 2007, doi: 10.1109/EDOC.2007.54.

[33] N. Lim, T. Lee, and S. Park, "A Comparative Analysis of Enterprise Architecture Frameworks Based on EA Quality Attributes,” 2009, doi: 10.1109/SNPD.2009.97.

[34] R. Rouhani, B. Darvish, F. Nikpay, Mohd Naz'ri Mahrin, and Pourya Nikfard, "A Comparison of the Top Four Enterprise- Architecture Methodologies," International Conference on Informatics and Creative Multimedia, 2013.

[35] M. A. Mohamed, G. H. Galal-Edeen, H. A. Hassan, and Ehab Ezzat Hasanien, "An Evaluation of Enterprise Architecture Frameworks for E-Government," IEEE, 2012.

[36] M. Kostoska, M. Gusev, and K. Kiroski, "Evaluation methodology for national enterprise architecture frameworks," in ICT Innovations 2010 Web Proceedings, 2010.

Appendix A. Selected tudies in review

\begin{tabular}{|c|c|c|c|}
\hline $\begin{array}{l}\text { ID } \\
\text { Study }\end{array}$ & Title & Source & Type Studies \\
\hline S1 & $\begin{array}{l}\text { GovQual: A quality driven methodology for E- } \\
\text { Government project planning }\end{array}$ & ScienceDirect & Journal \\
\hline $\mathrm{S} 2$ & $\begin{array}{l}\text { A Conceptual Framework for Enterprise } \\
\text { Architecture Design }\end{array}$ & Springer & Conference \\
\hline S3 & $\begin{array}{l}\text { A Centralized Design of Information Network } \\
\text { Architecture for Local Government }\end{array}$ & IEEE & Conference \\
\hline S4 & $\begin{array}{l}\text { A Method of Business and IT Alignment Based } \\
\text { on } \\
\text { Enterprise Architecture }\end{array}$ & IEEE & Conference \\
\hline S5 & $\begin{array}{l}\text { Designing an Enterprise } \text { Architecture } \\
\text { Government Organization Based on TOGAF } \\
\text { ADM and SONA }\end{array}$ & IEEE & Conference \\
\hline S6 & $\begin{array}{l}\text { Towards a Smart World Class City : Case: } \\
\text { Building Bandung ICT Master Plan }\end{array}$ & IEEE & Conference \\
\hline S7 & $\begin{array}{l}\text { Enterprise Architecture Design for } \text { Ensuring } \\
\text { Strategic } \\
\text { Business } \\
\text { (Integrating SAMM with TOGAF 9.1) }\end{array}$ & IEEE & Conference \\
\hline
\end{tabular}




\begin{tabular}{|c|c|c|c|}
\hline $\begin{array}{c}\text { ID } \\
\text { Study }\end{array}$ & Title & Source & Type Studies \\
\hline S8 & $\begin{array}{l}\text { E-Government Master Plan Design with } \\
\text { TOGAF Framework Case Study: Payakumbuh } \\
\text { City Government, Indonesia }\end{array}$ & IEEE & Conference \\
\hline S9 & $\begin{array}{l}\text { Implementation Of The Enterprise Architecture } \\
\text { Through The Zachman Framework }\end{array}$ & Emerald & Journal \\
\hline S10 & $\begin{array}{l}\text { Architecture Vision for Indonesian Integrated } \\
\text { Agriculture Information Systems Using } \\
\text { TOGAF } \\
\text { Framework. }\end{array}$ & IEEE & Conference \\
\hline S11 & $\begin{array}{l}\text { Customer oriented enterprise IT architecture } \\
\text { framework }\end{array}$ & ScienceDirect & Journal \\
\hline S12 & $\begin{array}{l}\text { A New Methodology For Developing The MIS } \\
\text { Master Plan }\end{array}$ & Googgle scholar & Conference \\
\hline S13 & $\begin{array}{l}\text { Enterprise architectures: enablers of business } \\
\text { strategy and IS/IT alignment in } \\
\text { government }\end{array}$ & Emerald & Journal \\
\hline S14 & $\begin{array}{l}\text { framework for e-government: privacy } \\
\text { implications }\end{array}$ & Emerald & Journal \\
\hline S15 & $\begin{array}{l}\text { The Four-Domain Architecture: An approach } \\
\text { to support enterprise architecture design }\end{array}$ & IEEE & Journal \\
\hline S16 & $\begin{array}{l}\text { Information technology portfolio management } \\
\text { implementation: a case study }\end{array}$ & Emerald & Journal \\
\hline S17 & Models for e-government & Emerald & Journal \\
\hline S18 & $\begin{array}{l}\text { E-government adoption: architecture and } \\
\text { barriers }\end{array}$ & Emerald & Journal \\
\hline S19 & $\begin{array}{l}\text { Bridging theory and practice in e-government: } \\
\text { A set of guidelines for architectural design }\end{array}$ & ScienceDirect & Journal \\
\hline S20 & $\begin{array}{l}\text { An enterprise application integration } \\
\text { methodology for e-government }\end{array}$ & Emerald & Journal \\
\hline S21 & $\begin{array}{l}\text { Interoperability frameworks and enterprise } \\
\text { architectures in e-government initiatives in } \\
\text { Europe and the United States }\end{array}$ & ScienceDirect & Journal \\
\hline S22 & $\begin{array}{l}\text { Essential Layers, Artifacts, and Dependencies } \\
\text { of Enterprise Architecture }\end{array}$ & IEEE & Conference \\
\hline S23 & $\begin{array}{l}\text { Business IT Alignment from Business Model } \\
\text { to Enterprise Architecture }\end{array}$ & Springer & Conference \\
\hline S24 & $\begin{array}{l}\text { Business and IT Alignment with SEAM for } \\
\text { Enterprise Architecture }\end{array}$ & IEEE & Conference \\
\hline S25 & $\begin{array}{l}\text { A Comparative Analysis of Enterprise } \\
\text { Architecture Frameworks based on EA } \\
\text { Quality Attributes }\end{array}$ & IEEE & Conference \\
\hline S26 & $\begin{array}{l}\text { A Comparison Enterprise } \\
\text { Implementation Methodologies }\end{array}$ & IEEE & Conference \\
\hline
\end{tabular}




\begin{tabular}{|c|l|c|c|}
\hline $\begin{array}{c}|c| \\
\text { ID } \\
\text { Study }\end{array}$ & \multicolumn{1}{|c|}{ Title } & Source & Type Studies \\
\hline S27 & $\begin{array}{l}\text { An effective Enterprise Architecture } \\
\text { Implementation Methodology }\end{array}$ & Springer & Journal \\
\hline S28 & $\begin{array}{l}\text { An Evaluation of Enterprise Architecture } \\
\text { Frameworks for E-Government }\end{array}$ & IEEE & Conference \\
\hline S29 & $\begin{array}{l}\text { Evaluation methodology for national } \\
\text { enterprise architecture frameworks }\end{array}$ & Goggle scholar \\
\hline S30 & $\begin{array}{l}\text { A Comparison of the Top Four Enterprise- } \\
\text { Architecture Methodologies }\end{array}$ & Goggle scholar & Conference \\
\hline
\end{tabular}

Appendix B. Theme of Selected Studies

\begin{tabular}{|c|c|}
\hline ID Study & Themes \\
\hline S1 & Elements of EA development \\
\hline S2 & Elements of EA development \\
\hline S3 & Elements of EA development \\
\hline S4 & Elements of EA development \\
\hline S5 & Elements of EA development \\
\hline S6 & Elements of EA development \\
\hline S7 & Elements of EA development \\
\hline S8 & Elements of EA development \\
\hline S9 & Elements of EA development \\
\hline S10 & Elements of EA development \\
\hline S11 & Elements of EA development \\
\hline S12 & Elements of EA development \\
\hline S13 & Elements of EA development \\
\hline S14 & Elements of EA development \\
\hline $\mathrm{S} 15$ & Elements of EA development \\
\hline S16 & Elements of EA development \\
\hline S17 & Elements of EA development \\
\hline S18 & Elements of EA development \\
\hline S19 & Elements of EA development \\
\hline S20 & Elements of EA development \\
\hline $\mathrm{S} 21$ & Elements of EA development \\
\hline $\mathrm{S} 22$ & Elements of EA development \\
\hline $\mathrm{S} 23$ & Elements of EA development \\
\hline S24 & Elements of EA development \\
\hline $\mathrm{S} 25$ & Criteria Methodology of EA development \\
\hline S26 & Criteria Methodology of EA development \\
\hline S27 & Criteria Methodology of EA development \\
\hline
\end{tabular}




\begin{tabular}{|c|c|}
\hline ID Study & Themes \\
\hline S28 & Criteria Methodology of EA development \\
\hline S29 & Criteria Methodology of EA development \\
\hline S30 & Criteria Methodology of EA development \\
\hline
\end{tabular}

